Western University Scholarship@Western

Centre for the Study of International Economic

Centre for the Study of International Economic

Relations Working Papers

Relations

1988

\title{
Monetarism, Microfoundations, and the Theory of Monetary Policy
}

David Laidler

Follow this and additional works at: https://ir.lib.uwo.ca/economicscsier_wp

Part of the Economics Commons

Citation of this paper:

Laidler, David. "Monetarism, Microfoundations, and the Theory of Monetary Policy." Centre for the Study of International Economic Relations Working Papers, 8807C. London, ON: Department of Economics, University of Western Ontario (1988). 
ISSN $\quad 0228-4235$

ISBN 0-7714-1023-9

THE CENTRE FOR THE STUDY OF INTERNATIONAL ECONOMIC RELATIONS

WORKING PAPER NO. $8807 \mathrm{C}$

MONETARISM, MICROFOUNDATIONS AND THE THEORY OF

MONETARY POLICY

David Laidler

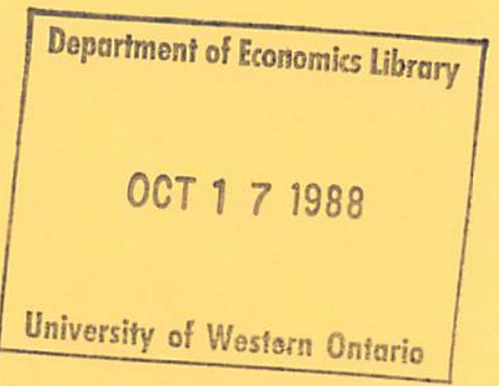

This paper contains preliminary findings from research work still in progress and should not be quoted without prior approval of the author.

DEPARTMENT OF ECONOMICS

THE UNIVERSITY OF WESTERN ONTARIO

LONDON, CANADA

N6A $5 \mathrm{C} 2$ 
MONETARISY, MICROFOUNDATIOUS AND THE THEORY OF MONETARY POLICY*

by

DAVID LAIDLER

* This paper has been prepared for presentation at a conference on Monetary Policy to be held at the Free University of Berlin August 31-September 2, 1988. I am grateful to Peter Howitt for helpful comments on an earlier draft. 


\section{INTRODUCTION}

The originators of new economic ideas seldom see them work out as they intended. Once published, they become common property and evolve in the most unexpected ways. This proposition might, upon close inspection, turn out to be something of an over generalisation, but it is surely true of that bundle of ideas commonly known as "Honetarism". Such commentators as Brunner and Heltzer (1987) and Leijonhufvud (1987) have noted, with alarm in the former case, and amusement in the second, the way in which a doctrine whose slogan was "money matters (and matters a great deal)" has during the 1980 s seemingly inexorably evolved into one in which money is to all intents and purposes irrelevant. This evolution ought to cause considerable concern to those interested in practical matters of economic policy.

Not the least of the accomplishments of Monetarism was to re-establish a public perception that monetary policy is important and it made its case not by deploying any radically new tools of economic theory but by drawing attention to empirical evidence. Over the last two decades, I would be prepared to argue, nothing has happened in the real world to contradict this perception. However, within the community of academic monetary economists, attempts to provide "sound" theoretical foundations for monetarism's empirical generalisations have led to the conclusion that the latter cannot be true. Whatever the textbooks of scientific method might advise to the contrary, economists have traditionally displayed a tendency to give priority to their theory when it comes into conflict with evidence, and that tendency seems to have been strongly at work in recent years. We thus find ourselves in a 
situation in which practitioners regard the conduct of monetary policy as important and the theory of monetary policy as interesting, while an increasing number of academics insist that the beliefs of practitioners about such matters are unsound.

In this essay I shall examine the evolution of the ideas that have led to this impasse. I shall begin with a brief account of the theory of macroeconomic policy as it arose in the context of the so-called "neo-Classical Synthesis", and show how Monetarism modified that theory. I shall then show how the search for sound microeconomic foundations for monetarist propositions ended up undermining them. Finally I shall argue that the currently accepted microfoundations of monetary economics are fundamentally flawed, and suggest that the practitioner's notions about the importance of money, which are largely a legacy of the monetary economics which preceded the search for microfoundations, can after all find a basis in an alternative theoretical framework.

II

MONETARY POLICY IN KEYNESIAN ECONOMICS AND MONETARISM

The economics of the neo-classical Synthesis, more usually and briefly, if inaccurately, called Keynesian economics, had as its centrepiece the Hicksian IS-LM diagram. ${ }^{1}$ This well-known device is beautifully calculated simultaneously to portray a particular problem, an hypothesis about its causes, and a theory about its cures. The problem is "unemployment equilibrium", the hypothesis is a failure of investment demand, and the theory of policy deals with the use of fiscal and monetary tools to influence real income and employment. 
Now even from the point of view of contemporary analysis, the unemployment equilibrium portrayed in IS-LM analysis is no equilibrium at all. It is, as Patinkin (1948) in particular made clear, more of a situation in which an economy might find itself from time to time, and from which it is thought unlikely to move towards a better ("full employment") state fast enough of its own accord. The explanation offered for the existence of unemployment would hardly pass muster by today's theoretical standards. The inadequate level of the marginal efficiency of capital underlying unemployment equilibrium arises outside of the IS-LM model, which however efficient it might be for deducing the consequences of such a state of affairs, has nothing to say about its causes. Nevertheless, this framework formed the basis of a theory of macroeconomic policy which dominated the discipline for three decades, and whose influence now is still clearly to be seen in the structure of virtually every econometric forecasting model of which I am aware. 2

The theory of policy to which I have referred amounts to a set of instructions: forecast investment demand (and perhaps exports too in the case of a significantly open economy); calculate the implied shortfall of actual from desired output; manipulate either monetary variables, and in particular the rate of interest, in order to induce a higher level of investment, and/or the twin fiscal variables government expenditure and taxes, to make good the shortfall directly. To the extent that time lags in the effects of policy appear to present a problem, their consequences can be offset as they arise by further manipulation of policy variables. ${ }^{3}$

Though these instructions, and indeed the logic of the IS-LM model, leave room for monetary policy to be used as an instrument of stabilisation policy, the whole thrust of "Keynesian Economics" as a policy doctrine was to emphasise fiscal policy. The "liquidity trap" doctrine, and more generally the notion that the demand for money was highly interest sensitive and perhaps 
unstable, suggested that the links between the LY and IS sides of the model, and by implication of the real world too, were weak and unreliable; and in any event it surely made sense to offset the consequences of one factor (investment demand) shifting the Is curve by directly manipulating other variables that could shift the same curve in the opposite direction. The role of monetary policy was thus reduced to the supporting one of perhaps supplementing, but at least not interfering with, the conduct and effects of fiscal policy.

Now all this leaves out of account a number of questions that immediately come to the mind of an economist trained in the 1980s. First of all, it might reasonably be asked, where does the behaviour of the price level come into all this? The IS-LM model can of course be deployed to analyse the inflationary effects of a level of aggregate demand in excess of "full employment" output. Thus, the first edition of my own Demand for Money (Laidler 1969) used the behaviour of the model in both unemployment and full employment modes to motivate its entire discussions and Friedman (1971) used it as a device for expounding many characteristic "monetarist" ideas about just these matters.

However IS-LM is a clumsy device to use for analysing price level fluctuations. The Phillips curve, in its original form, was quickly absorbed into maintstream macroeconomics because it provided a simple way of dealing with inflation as a policy problem. It treated the value of the inflation rate as a side effect of the chosen target level of employment, a side effect that nowhere fed back into the system, and one which could be mitigated by other policies designed to "shift the Phillips curve". Aggregate demand was, in the "Keynesian" view, just one, albiet in the view of some (e.g. Samuelson and Solow 1960) important, influence on the inflation rate. Since monetary policy was in its turn also just one factor impinging upon aggregate demand, and an 
unimportant one at that, it had no special role to play vis-a-vis inflation in the economics of the 1960 s.

The macroeconomics of the neo-classical synthesis thus downgraded monetary variables, and yet the first round of the Monetarist challenge to that doctrine involved an attack on the effectiveness of monetary pollcy as a device for "fine tuning" the economy based on the proposition that its effects were subject to "long and variable" time lags. At first sight, this attack seemed misdirected, and yet Keynesians rose to its challenge and in due course came to defend monetary policy as a tool of stabilisation policy. The clue to understanding why this happened lies in the fact that this stage in the development of the theory of monetary policy took place in the United States. Stabilisation policy requires considerable institutional flexibility, in order that the time lags involved in the recognition of a problem, and in the design and implementation of policy, are short. In the case of monetary policy, such flexibility is available to central banks that are unencumbered by constitutional or quasi-constitutional constraints. When it comes to fiscal policy, it is provided by parliamentary systems of government on the British model, but not by the American congressional system.

The tax-cuts implemented in the United States in 1964 were at the time hailed as a triumph of Keynesian fiscal policy, but they were proposed in 1962. To hold up a measure that took two years to implement as an example of active stabilisation policy is surely preposterous, for what this episode brings home is that, in the United States, such policy has to be carried on by monetary means or not at all. Fiscal tools are simply not available for this purpose. Though this point is seldom if ever made explicitly, it is of vital importance in understanding why the theory of monetary policy has developed as it has. The literature of macroeconomics since the second-world 
war is predominantly American, and a particular institutional peculiarity of the United States has come to colour a whole body of apparently "general" literature to the point at which faith in the efficacy of monetary stabilisation policy has come to be regarded as the hallmark of "Keynesianism", and a denial of that efficacy a characteristic "anti-Keynesian" position."

There was more to the rise of Monetarism than the peculiar importance thrust upon monetary measures by the institutional framework of the American economy. As Harry Johnson (1971) long ago noted, it was also associated with the emergence of inflation as a serious policy problem. The modern Quantity Theory of Money of Friedman and his associates was far from being a simple revival of the pre-General Theory doctrines that carried the same label, but it did have one all important proposition in common with those earlier ideas: namely that variations in the quantity of money in circulation were an important independent cause of variations in the price level. ${ }^{5}$ The fact that, by the early 1970s, inflation was a world wide problem combined with the apparent success of monetarist hypotheses about the stability of the demand for money function (a necessary condition for the truth of a monetary explanation of inflation) to ensure that the theory of monetary policy associated with Honetarism attracted international attention in a way that earlier arguments about the unsuitability of monetary measures for fine tuning had not. The suitability or otherwise of monetary tools for counter-cyclical policy was a contentions issue mainly in the United States, but a monetary explanation of inflation had a much wider appeal.

It will be helpful to summarise just what the Monetarist theory of monetary policy amounted to. First of all it asserted not just that inflation was an important and undesirable phenomenon. It also asserted that inflation 
was predominantly the long run effect of monetary expansion, and that fluctuations in money growth had short run effects on real-income and employment. Hence a monetary theory of inflation was supplemented with a monetary explanation of cyclical fluctuations. The short-run effects of monetary policy though, were subject to long and variable lags (between six and eighteen months) and hence could not be exploited in the design of stabilisation policy. However, since they were the main cause of cyclical fluctuations in the first place, this presented no real problem. Eliminate fluctuations in money growth and the cycle would be to an important extent stabilised by that very act. Thus, if the rate of growth of the money supply was set roughly equal to the secular rate of growth of output by a rule (either self imposed by the central bank, or imposed upon it through political processes), long run price stability would be assured, and short run real income and employment stability would be enhanced significantly. 6

Now of course this theory of policy was never more than partially implemented in the 1970 s and 1980s, and as I have argued elsewhere (Laidler 1986), widely held perceptions to the effect that it failed in practise are largely (not entirely) misconceived. However the actual policy experience of the last two decades does not present the only challenge to monetarist views about the appropriate conduct of monetary policy that has emerged over that period. They have also come under a theoretical attack which has done more to undermine their academic prestige than any empirical evidence. The capacity of monetary fluctuations to have significant real effects, not to mention the destructive nature of price level variations in general and inflation in particular, have been challenged; so too has the basic proposition that variations in the quantity of nominal money will in general have a significant influence on its value, not to mention the basic preconception underlying all 
mainstream discussion of monetary policy since the mid-19th century that the behaviour of monetary variables is a matter that government ought to concern itself with. Horeover this radical attack has emerged not from a self-conscious attempt to undermine monetarism, but from analysis whose initial intention was to strengthen its theoretical foundations.

\section{III}

\section{MICROFOUNDATIONS AND THE NEW MONETARY ECONOMICS}

I have already remarked that the IS-LM framework was well designed to enable economists to make deductions about shifts in underlying behaviour relationships, notably investment demand, for real income and employment, and, when supplemented by the Phillips curve, about inflation too. It did not, in and of itself have anything to say about those underlying behaviour relations. The latter issues were the concern of microeconomics, and the 1950 s and 60 s generated a rich literature on the maximising foundations of the consumption, demand for money and investment functions. ${ }^{7}$ The micro-foundations of the Phillips curve too attracted attention, and the insights of Phelps (1967) and Friedman (1968) about the importance of expectations about the future behaviour prices for the present behaviour of wages and hence of prices provided the basis of those characteristic monetarist propositions about the short and long run effects of monetary policy which I have already discussed above. However, this work had another less immediate but in the long run far more profound effect on the development of macroeconomics about which something should now be said.

If the expected future behaviour of prices affects their current behaviour, and if that behaviour is generated by the macroeconomic system, then beliefs about how that system works must themselves be fundamental 
components of the microeconomic framework underlying the behaviour of the aggregate economy. Horeover the beliefs of agents, to be sustainable, had better be compatible with the structure of the economy to which they appertain. A critical implication of these insights, which arise from Lucas's (1972) seminal work on the macroeconomic consequences of "Rational Expectations", was that the investigation of the nature of the markets in which agents interact replaced further elaboration of the microeconomics of particular behaviour relations at the very top of the research agenda of macroeconomic theory. Two characteristics of traditional IS-LM analysis, which had been taken over by monetarists and adapted to their own purposes by the time Lucas's work was published, have proved critical for the way in which such questions have been tackled. The first of these is that the system utilises a largely unquestioned assumption of nominal price stickiness from which the possibility of the occurence of underemployment derives. The second is that the framework embodies the characteristic Walrasian vision of economic variables being simultaneously determined by the contemporaneous interaction of agents in what is essentially a single market.

If prices are sticky, the reason for that needs to be explained, and a model of the forces driving their behaviour derived, before a satisfactory theory of how expectations about price fluctuations are formed can be constructed. Hicroeconomics though, provides no such theory that can easily be embedded in a general equilibrium framework. ${ }^{8}$ on the other hand the theory of competitive markets, based on the idea of complete price flexibility, does at least enable endogenous price expectations to be modelled systematically, and it had already been shown, by Lucas and Rapping (1969) among others, before the advent of rational expectations, that quantity fluctuations could be reconciled with price flexibility provided agents were permitted to make 
expectational errors. Hence the price stickiness assumption became anathema; but once it was dropped IS-LM in effect reverted to being a particular and rather ordinary version of Walrasian General Equilibrium model. 9 In the process of acquiring market-theoretic microfoundations, Hacroeconomics thus lost its separate identity. Also, and crucially for the topic of this paper, the scene was set for a wholesale revision of the theory of monetary policy which would downgrade the significance of money to a degree far greater than had Keynesian Economics.

This is a claim that needs defending, because the change that Lucas and his associates seemed to have made to macroeconomics in the 1970 s was to provide a better theoretical basis for monetarism, a doctrine for which money mattered above all other things. Certainly in their analysis money caused real variables to fluctuate in the short run, and prices in the long run just as it did in Friedman's work. However, short run real effects depended upon monetary changes being unanticipated. Hence, any systematic rule for the behaviour of the money supply, and not just a constant growth rate rule, would stabilise real variables. Only to the extent that anticipated inflation might lead to non-super-neutrality and impose welfare losses on the economy did the choice of a time path for the money supply matter at all. Both of these implications of new-classical macroeconomics have led to trouble as far as the theory of monetary policy is concerned. 10

Consider the question of short run effects first of all. If agents really do form their expectations about the behaviour of the money supply in a manner that is commonly called "rational", only random fluctuations in the money stock can possibly have real effects. Monetarism attributed a dominant role to monetary fluctuations in driving the business cycle, but it is hard indeed to think of the history of cycles as reflecting merely the consequences of a series of random shocks to the money supply. Indeed the plausibility of 
such an explanation is further undermined by the observation that data on the money supply are nowadays readily available on a weekly basis to anyone who cares to look them up in a newspaper. To be sure, as Boschen and Grossman (1982) pointed out, these data are subject to reporting error, but it does indeed stretch one's credulity to attach much responsibility for current business fluctuations to such a transitory phenomenon; and, in any event, their empirical results showed that this implication of a literal interpretation of new-Classical analysis was quite inconsistent with the data. In short if one insists on maintaining price flexibility and rational expectations assumptions, it is difficult to accord money any significant influence over real income and employment, even if that does involve ignoring Boschen and Grossman's finding that announced and therefore readily observable fluctuations in the money supply do appear to cause output fluctuations.

Not only does acceptance of new-Classical analysis undermine on a priori grounds the importance of money as a causative factor in short run fluctuations. It also downgrades the importance of stabilising the cycle as a goal of macroeconomic policy. Even if the cycle was largely driven by random monetary impulses, only the initial response of output and employment to them can in any sense be regarded as sub-optimal. Subsequent fluctuations must reflect the economy's optimal response to the situation created by the initial shock. If the cycle is primarily the result of other impulses such as the shocks to the production function postulated by Kydland and Prescott (1982) then even the initial fluctuation becomes a reflection of optimising behaviour. Now there is some value in these implications of new-classical analysis. We ought not to take it for granted, as we so often do, that smooth growth is optimal and that any departure from this pattern is undesirable and hence worthy of policy correction. The question does need re-examining. In 
the current context, however, the key point is that the answer given by new-Classical analysis leaves no interesting role for money to play either as cause or cure of the cycle. That analysis, if it is taken seriously, thus destroys an important component of the traditional theory of monetary policy. The component in question is of course a comparitively recent addition to the area. It was only in the first two decades of this century that the possibility that monetary impulses might cause the cycle, and that monetary policy might and ought to be used to stabilise it, came to be seriously entertained by economists. ${ }^{11}$ In earlier times, monetary policy was concerned with inflation and avoiding collapses of the monetary system rather than stabilising real income and employment. In the context of inflation too, new-Classical economics or at least one offshoot of it downgrades the significance of monetary policy. I remarked earlier that Monetarism treats inflation as an important problem, premising its concern on an analysis of non-superneutralities of money and their associated welfare costs. The latter were traditionally measured by an area, typically a triangle, under the demand for money function, and have long been a target of those who would downgrade the importance of money. To such Keynesians as James Tobin (1977) - It Takes a heap of Harberger Triangles to fill an Okun Gap"- the relatively small size of the welfare costs of inflation thus assessed did not seem to justify the strength of monetarists' concerns about inflation, but the critique implicit in the so called "New Monetary Economics", to whom the most visible contributors are Hall (1982) and Sargent and Wallace (e.g. 1982) goes much deeper.

Once again it is a matter of seeking microfoundations for a piece of macro analysis, in this case the aggregate demand for money function. 1960s vintage monetarism typically treated real balances "as if" a consumer durable 
good, and included their "services" in agents' utility functions. The New Monetary Economics asked what those services might consist of, and could find no answer arising within the structure of the the General Equilibrium Model with which it was operating. The reason for this is obvious enough. To apply Walrasian market theory is to assume that the world operates "as if" market clearing prices are costless to set, and as if the act of exchange is subject to no frictions. Hence a Walrasian model leaves no role for money to perform services as a means of exchange. Moreover the implicit assumption of rational expectations modelling, that agents can costlessly process and comprehend all information that is available to them, leaves no role for money to perform a useful service as a unit of account either. The only function for money that can arise in such a world is that of a store of value, and the "services" that it yields to agents can only take the form of pecuniary return.

To treat money in this way of course immediately rules out of court the traditional analysis of the welfare costs of inflation. Indeed it goes much further, because any expected rate of return on money below that yielded by productive assets (including inventories of consumption goods if these are storable) will lead to its not being held at all. If money bears explicit interest at the market rate, it becomes indistinguishable from other assets, but if it does not and consists of some intrinsically valueless item, then expected inflation at any rate in excess of minus the real rate of interest immediately leads to money's disappearance from the economy, which nevertheless continues to function in its absence! This is not to say that an equilibrium in which money is held may not be preferable to one in which it isn' $t$, because it might be, but it is to say that in the New Monetary Economics, the welfare analysis of money is completely disconnected from price level fluctuations per se. As Neil Wallace once put it "so far as we know the 
claim that a stable price level is good is as naive as the claim that a stable relative price between, say eggs and steel is good. In fact it has been argued that the two are on the same footing" (Wallace 1982. p. 229).

The existence of a non-interest bearing intrinsically valueless store of value, which is what the Mew Konetary Economics means by fiat money, is certainly theoretically fragile, and the central question addressed by this body of analysis is how it can be that money's existence can be so pervasive a phenomenon in the real world. The answers that it offers are twofold. First it is argued that fiat money is a creation of the state, and would be unlikely to exist in the absence of legal requirements that it be held. The alternative to this "legal restrictions" explanation of money's existence is that non-fiat money, in the form of well defined claims over intrinsically valuable (i.e. utility yielding) goods, is the only type of money that is generally viable in an unregulated market. In this view, then, it is the "backing" of money that matters, both for its capacity to exist, but also for the determination of its value. The price level no longer varies with the quantity of nominal money, then, but as a function of the expected future price level whose behaviour in turn is dominated by the nature of monetary regulations and the quality of money's backing. 12

This line of argument yields an immediate and quite distinctive implication for the theory of monetary policy: that private agents can safely be left to provide on their own account well backed stores of value without the intervention of government; and that legal restrictions which cause government fiat money to be held are likely to be welfare reducing; in short that monetary policy carried out by government is itself the problem, and not the solution to any problem arising elsewhere in the economy. There is a 
strong affinity between the New Monetary Economics and the arguments of 19th and early 20 th century advocates of Free Banking, as, for example Cowen and Krozner (1987) have pointed out, but, as they also point out, the exclusive concentration of the more recent literature on money's store of value role adds an extra touch of radicalism to its message.

These developinents in monetary theory have, until now at least, left practical policy discussions largely untouched. Monetary policy is still in most countries carried on on the basis of analysis directly derived from the neo-Classical synthesis heavily coloured by monetarist ideas. By that I mean that monetary aggregates now play a much bigger role relative to interest rates in the design of policy than they did twenty years ago, that monetary measures in general are regarded as far more important relative to fiscal policy than they were then, and that active attempts to stabilise the economy by monetary means, though not (unfortunately in my view) entirely abandoned, are much more likely to be subordinated to longer term price stability goals. Policy is thus still based upon what almost any academic monetary economist would regard as at best old-fashioned, and at worst hopelessly obsolete and inadequate, theory. However, the prospect of a monetary regime based upon the tenets of the New Monetary Theory is not an attractive alternative. It would attempt to take money out of the political arena and leave its behaviour to the market, and I do not believe that that would be either desirable or feasible, as I shall now attempt to explain.

IV

MONEY AS A PUBLIC GOOD

Perhaps the most extraordinary development in monetary theory over the past fifty years is the way in which money's means of exchange and unit of 
account roles have vanished from what is widely regarded as the mainstream of monetary theory. The potential for such a disappearing trick was already inherent in IS-LM analysis, as such commentators as Clower (eg. 1968) long ago noted, but it has been the New Monetary Theorists who have brought it to full fruition. As I have already pointed out, their adoption of the assumption of competitive clearing markets as an unquestioned starting point for analysis leaves money no room to work as a means of exchange, and their similar treatment of the particularly extreme form of rational expectations that grants to all agents equal access to all available information in the economy, and free use of whatever analytic and computational skills are needed to process it, renders a unit of account function equally nugatory. In models based on such assumptions "money" can only appear as a store of value that yields purely private returns to the particular agents who hold it. Such models are therefore bound to yield the policy implication that private competitive markets can be relied upon to provide the amounts of money that agents want to hold and that government interference with their operation can only make matters worse rather than better.

Money is not just a store of value however. It is a medium of exchange and a unit of account, and in those roles the services it yields are inherently public. Competitive equilibrium analysis of the type that underlies the New Monetary Economics cannot comprehend these roles because the Walrasian market is an alternative social institution to money, not a complementary set of arrangements. To the best of my knowledge, no-one has ever suggested that it is the task of economic theory to deduce the existence of a competitive Walrasian market from maximising assumptions. Rather we are satisfied to have theory tell us what public benefits, involving the transmission and processing of information and the elimination of transactions 
costs, such a market bestows upon all who participate in it. But the social benefits which any microeconomics text attributes to "the market" include those which any macroeconomics text attributes to a system of monetary exchange. If a monetary economy solves the same problems as would a competitive market, it might often be safe to assume that it acts "as if" it were in fact a market economy, and that is why conventional microeconomic analysis is a useful tool for analysing the real world. However, when it comes to analysing the processes of disseminating and processing information themselves, and those of co-ordinating activity, it is important to choose between assuming a monetary economy and a Walrasian market economy. It is a fundamental error to assume the existence of a clearing walrasian market as the first step of an attempt to understand money.

The implications of the foregoing arguments for the theory of monetary policy are straightforward. That theory must start from the fact that money is a social institution whose services are inherently public if it is to be satisfactory, but if we start from this premise, we must treat the design of monetary institutions as a political matter, because political processes exist, among other reasons, to help us internalise those externalities that voluntary private contractual arrangements cannot cope with. ${ }^{13}$ We must, however, be careful what we deduce from this observation. In particular it does not inevitably imply that the monetary system must be provided by the public sector, or that indiscriminate public regulation of private sector agencies within the monetary sector must be regarded as either inevitable or desirable. All it implies is that choices about the design of the monetary system and the way it is to operate are inherently political matters which cannot be settled in the market place. The theory of public goods tells us that the demand for them must be articulated by a collective agency; it does 
not also say that they must be collectively supplied. A political decision to have unregulated private agents provide a monetary system may, then, be a viable option.

The public good which a monetary system provides, and the demand for which must be collectively articulated arises immediately from money's unit of account and means of exchange roles. Economic computation is costly, as is the formulation of contracts, no matter what the latest in economic theury might assume to the contrary about these things. A common unit of account does make life easier for all concerned, and easier still if its value in terms of goods and services is stable and predictable (I deliberately avoid the word "constant" here) over time. Moreover stability of the value of the economy's means of exchange in terms of the unit of account also simplifies the planning of and execution of market transactions. ${ }^{14}$ The maintenance of a stable and predictable time path for the purchasing power of money thus bestows benefits on all agents in the economy simultaneously, no one can be excluded from enjoying those benefits, and the marginal cost of extending them to extra members of the economy is zero.

Price level stability is, therefore, a public good, in exactly the same way as a well defined system of exchangeable property rights is a public good (or for that matter as a Walrasian market presided over by an auctioneer would be a public good were such an institution ever to exist). The theory of monetary policy must then be concerned with the provision of an optimal time path for the purchasing power of money for a world in which making economic calculations and predictions is costly, and in which those costs vary with the nature of the time path in question. There is no need in the current context to offer a precise suggestion as to just what that time path should be. Suffice it to mention some of its characteristics. 15 
Computations involving a constant rate of change of prices are easier than those in which it varies, so there must be a presumption that variable inflation (or deflation) is sub-optimal. Moreover, the marginal costs of providing real balances in a non-commodity money system are zero (which does not mean that the fixed costs of establishing such a system are also trivial); but the support that this consideration gives to deflation at the real rate of interest as a policy goal must be weighed against "menu-cost" considerations. These imply that, when individual price changes are costly, a time path for the price level which reduces their frequency saves real resources. Moreover, the fact that some prices (e.g. money wages) are more costly to change than others has implications for the choice of just which price index to choose as a basis for policy. In practice then, the selection of the optimal price level goal is very much a matter of complex "second best" calculations, but ancient platitudes about not letting "the best become the enemy of the good" apply with a vengeance in this case. The presumption that a low and stable rate of change of some representative price index is more desirable than high and variable inflation is strong. We should not, therefore, let difficulties of discovering a precise goal distract us from the importance of remaining in its vicinity.

Now we cannot take for granted the existence of a benevolent social planning agency dedicated to promoting the public welfare, so the theory of monetary policy has to concern itself with the design of those institutions intended to produce and maintain price stability. Here there is scope for considerable private sector involvement in the provision of the public good under consideration, because old arguments in favour of "free banking", notably those recently revived by Hayek (1976) and White (1984), have a great deal to be said for them. Elementary economic theory tells us that competitive 
institutions will provide their output up to the point at which their price equals marginal cost. In the case of banks, the relevant product is real balances, and the relevant marginal cost is approximately zero. This by itself does not guarantee stability of the purchasing power of any bank's liabilities. All it implies is that they will bear a nominal rate of return equal to the real rate of interest plus their expected rate of depreciation; but the imposition of any computation or transactions costs on either the emitters or holders of the liability of any particular bank by a non-zero value for the latter component of their nominal return will lead to market mechanisms eliminating it and generating constant purchasing power for competitively issued bank money. 16

If things were really that simple, then the private sector, completely unregulated, could be relied upon to provide a sound monetary system, but they are not. To begin with, the promise of stable purchasing power on the part of competitive bank liabilities must be credible, and that is best ensured by each bank standing ready to redeem its liabilities in something which is itself of stable purchasing power. In principle this could be a "representative" bundle of goods stored by the bank, but considerations of costs and convenience suggest that it will be some claim to such goods, and that each bank will find it convenient to use the same claim as a first line reserve. A competitive banking system thus requires what we usually call "high-powered money" in order to settle clearing balances. Moreover, because of those economies of scale in reserve holding that have been well known since the work of Edgeworth (1887), there is a tendency to natural monopoly inherent in its provision. The existence of a central "reserve agent" as the modern literature calls it is not a product of regulation, but a natural consequence of the operation of a competitive banking system. When natural monopoly arises 
in the provision of a public good, one is bound to end up with either a public sector or a highly regulated private sector enterprise.

A central bank on the Bank of England model is one type of reserve agent. It is not necessarily the best model to follow, but the idea that central banks as we know them can be abolished without any other entity taking their place is not well founded. Nor is it the case that the existence of a central reserve agent marks the only departure from some atomistically competitive norm which economic theory suggests might characterise the institutions involved in the efficient private provision of money. Given the existence of a stable high powered money, a competitive banking system will generate price level stability only if the behaviour of the non-bank public makes it unprofitable for any individual bank to over-issue its own liabilities. If such liabilities are deposits, then an adverse clearing balance will immediately face the overissuing bank and force it to mend its ways. If they are notes, then only if the public returns them for redemption to the issuing bank will such discipline be imposed. To spend a deposit automatically brings the clearing mechanism into play, but to spend a note does not. The public needs much more information about individual banks of issue than about deposit banks in order to discipline them. This well known 19 th century argument may still be used today to justify restrictions on competitive note issue; and is it not efficient to place a monopoly note issue under the control of the reserve agent and use it as high powered money? Nor should we ignore the reserve agent's potential lender of last resort function. Were bank liabilities a pure store of value, it could be argued that the rule of caveat emptor should be applied to those who had chosen to hold those emitted by badly run institutions. Only arguments about 
externalities in the provision and dissemination of information could be used to soften this stance. However if private bank liabilities function as a means of exchange, then a social institution, namely the system of monetary exchange, is threatened by bank failures and there is a case to be made for public intervention. This does not mean that each and every badly run bank should always be bailed out, but it does mean that a public interest must always be weighed when a decision is taken about such an issue. To give the reserve agent a discretionary lender of last resort function, then, is to create an arrangement to cope with a major externality. It is not to impose an unnecessary complication on the structure of an already ideally designed banking system.

Now the monetary system which I have just described turns out to look very much like the one we have. However, the existence of a central reserve agent, and its lender of last resort role and perhaps its monopoly of note issue too, are, according to the arguments I have presented, responses to economic problems created by the very nature of money and monetary exchange. They are not the consequences of capricious intervention by an incompetent government which is the enemy of economic efficiency. Once one abandons the implausible notion that money is a store of value pure and simple which dominates the modern literature on the micro-foundations of money, and realises that this view of things stems from the fundamental unsuitability of Walrasian General Equilibrium Theory for the analysis of those microfoundations, it appears that government is after all an inherent part of an economically efficient solution to monetary problems. 17

However, just because government is needed to cope with monetary problems does not mean that its actions will always be disinterestedly chosen or competently executed. It is a well known commonplace of the literature on 
microeconomic policy issues that considerations of externalities, public goods and the ethics of the distribution of wealth all create problems that only a collective agency can solve, and it is equally well known that a mere fraction of the government interventions which we see in real world economic life can stand scrutiny as attempts to cope honestly with such problems. The traditional questicns of the monetary policy literature about the use of rules or discretion in the conduct of policy, about the extent to which the reserve agent should regulate the behaviour of deposit banks, about how that agent should carry out its lender of last resort role, about the appropriate choice of international monetary system for a world where the highest level of political authority is the nation state, are after all real issues that are still worth arguing about. They are not, as the New Monetary Economics would have it, artificial problems created for government by government.

\section{V \\ CONCLUDING COMENTS}

The intention of this paper has been to argue that the traditional problems of the monetary policy literature raised in the last paragraph are after all real problems worth arguing about. To the practitioner of monetary policy, or the interested layman, it might seem already clear that this is the case. The fact that in this instance I share the non-academic's judgement, does not mean that it is pointless to put a little effort into restating the obvious. Though the policy framework at present in place in most countries does not seem to be too badly designed, and though the day to day conduct of monetary policy is not too bad either, at least by recent historical standards, there can be no guarantee that either the policy framework or the actual conduct of policy will continue basically unchanged into the future. 
Economic theory of the most abstract sort has, as Keynes (1936) long ago noted, a way of influencing practical policy in the long run. One body of analysis currently attracting a good deal of attention in the academic community, namely the New Honetary Economics, has profound implications for policy, but these arise, I have argued, from its being premissed upon a basic misconception concerning the role of money in the economy. The New Monetary Economics, therefore, seems to me to present something of a long run threat to monetary stability in the real world, a threat to which it has been the aim of this paper to offer a little opposition.

There are, of course many other threats to monetary stability. To say that collective agencies of some sort have an inherent role to play in the workings of the monetary system is not to guarantee that they will be well designed in detail or that they will play their part in a satisfactory way. Nor indeed is it to say that there is any unanimity among monetary economists on just what a "well designed" monetary authority would look like, or what "satisfactory" conduct on its part would be. To define the frame of reference for debates about monetary policy as I have attempted to do in this essay is not also to specify their outcome. I have discussed these other issues elsewhere (eg 1986). That I do not take them up here simply reflects the fact that one can only deal with so much material in one paper; it does not imply that I regard these issues as unworthy of discussion. 
FOOTNOTES

1

Hicks (1937) is the locus classicus of this diagram.

2 The Liverpool model of the U.K. probably goes further beyond an orthodox IS-LM structure than any other forecasting model. Nevertheless, the demand side of this model does have a familiar look to it! See Minford (1980) for a readily available account of this system.

${ }^{3}$ Lerner (1951) provides a good example of this strand of thinking about the problem of time lags. It was not until the work of Phillips (eg. 1954) that the serious nature of this problem for stabilisation policy came to be widely appreciated.

${ }^{4}$ One can do no better than cite the presidential addresses to the American Economic Association of Milton Friedman (1968) and Franco Modigliani (1977) to illustrate this assertion.

${ }^{5}$ But the emphasis on the importance of money relative to that of other factors is stronger in Friedman's work than in the typical pre-General Theory account of the quantity theory.

${ }^{6}$ The locus classicus for this position is, of course, Friedman (1959)

${ }^{7}$ On the consumption function see Modigliani and Brumberg (1954) or Friedman (1958), on investment see Jorgenson (1963), and for a survey of the literature on the demand for money see Laidler (1969) Pt. II.

${ }^{8}$ Hicroeconomics does of course provide a rich array of partial equilibrium treatments based on models of oligopoly behaviour. See, eg. Kawasaki McMillan and Zimmerman (1983)

${ }^{9}$ This much of course was already apparent to anyone who had read the sections of Patinkin (1956) that dealt with price flexibility. 
${ }^{10}$ On the significance of unanticipated monetary changes for real variables see Sargent and Wallace (1976). For a survey of the salient results on super-neutrality, see Laidler and Parkin (1975) Pt. 2.

${ }^{11}$ The two best known advocates of a monetary theory of the cycle during this period were probably Irving Fisher (eg. 1911) and Ralph Hawtrey (eg. 1913).

12 And as I noted in Laidler (1987) this prediction hinges upon the demand for money being highly elastic with respect to the opportunity cost of holding it. In this sense, the "backing" theory of money bears an uncanny resemblence to the Keynesian theory of the speculative demand for money.

${ }^{13}$ See Weldon (1973) for a pioneering discussion of the public good aspects of money, and Vaubel (1986) for a recent and extensive discussion of the pros and cons of treating money as a public good, and its implications for the desirability of competitive monetary regimes. Vaubel is reluctant to treat money as a public good, lest he abandon the case for competitive money in the process.

${ }^{14}$ This is not a view that everyone would share. Cowen and Krozner (1987) is an excellent source of information on the literature, both old and new, which makes the case for separating money's unit of account and means of exchange functions.

${ }^{15}$ I am well aware that a full discussion of the aims of monetary policy should deal with the desirability (or otherwise) of using it as a tool for stabilising real variables. I have discussed this matter at some length elsewhere (Laidler 1986), and neglect it here for lack of space rather than from a lack of things to say on the topic. Suffice it here to say that I would prefer to direct fiscal policy to stabilisation goals. 
${ }^{16}$ A much neglected, but excellent, commentary on the links between competition and efficiency in the provision of monetary services is Johnson (1968)

${ }^{17}$ Note that this conclusion runs contrary to that of Bagehot (1873) who regarded a competitive monetary system with decentralised reserves as "natural" and the system he actually described and defended as being the product of fortuitous government intervention in financial markets. 
REFERENCES

Bagehot W. (1873) Lombard Street: A Description of the Money Market London. Boschen J. and Grossman H. I. (1982) "Tests of Equilibrium Macroeconomics Using Intertemporal Data" Journal of Monetary Bconomics 10, 309-333.

Brunner K. and Meltzer A. H. (1987) "Honey and the Economy: Issues in Monetary Analysis" (The 1987 Raffaele Mattioli Lectures) Carnegie Mellon University (mimeo)

Clower R. W. (1967) "A Reconsideration of the Microfoundations of Monetary Theory" Western Economic Journal 6 (Dec.) 1 - 8.

Cowen $T$. and Krozner R (1987) "The Development of the New Monetary Economics" Journal of Political Bconomy 95 (June) 567-590.

Edgeworth F. Y. (1887) "The Mathematical Theory of Banking" Journal of the Royal statistical society.

Fisher I. (1911) The Purchasing Power of Money New York, Macmillan.

Friedman M. (1958) A Theory of the Consumption Function Princeton N. J., Princeton Univ. Press for the MBER.

(1959) A Program for Monetary stab1lity New York, Fordham

Univ. Press.

(1968) "The Role of Monetary Policy" American Bconomic Review

58 (March) 1-17.

(1971) "A Monetary Theory of Nominal Income" Journal of Political

Economy 79 (Mar.-Apr.) 323-337

Hall R. (1982) "Monetary Trends in the United States and the United Kingdom:

a Review from the Perspective of New Developments in Honetary Economics" Journal of Economic Literature 20 (Dec.) 1552-1555. 
Hawtrey R. (1913) Good and Bad Trade London, Constable.

Hayek F. A. von (1976) Denationalising Money London, IEA.

Hicks J. R. (1937) "Mr. Keynes and the Classics: a Suggested Interpretation" Econometrica (reprinted in Critical Essays in Monetary Theory Oxford, Clarendon Press 1967).

Johnson H. G. (1968) "Problems of Efficiency in Monetary Management" Journal of Political Economy 76 (Sept.-Oct.) 971-990.

(1971) "The Keynesian Revolution and the Monetarist CounterRevolution" American Economic Review 61 (May, Papers and Proceedings) 1-14.

Jorgenson D. W. (1967) "The Theory of Investment Behaviour" in Ferber (ed.) The Determinants of Business Behaviour NBER.

Kawasaki S, McMillan J. and Zimmerman K. F. (1983) "Inventories and Price Inflexibility" Econometrica 51 (May) 599-610.

Keynes J. M. (1936) The General Theory of Employment Interest and Money London, Macmillan.

Kydland F. and Prescott E. (1982) "Time to Build and Aggregate Fluctuations" Econometrica 50 (Sept.) 1345-1370.

Laidler D. (1969) The Demand for Money: Theortes and Bvidence (1st ed.) Scranton Pa., International Textbook Co. (1986) "What Do We Really Know about Monetary Policy" Australlan Bconomic Papers (June) 1-16. (1987) "Fisher and Wicksell on the Quantity Theory and the Backing of Money: a Comment on the Debate between Bruce Smith and Ronald Michener" in Brunner K. and Meltzer A. H. (eds.) Carnegle-Rochester Conference Series on Public Policy Vol. 27 325-334. and Parkin J. M. (1975) "Inflation - a Survey" Economic Journal 85 (Dec.) 741-809. 
Leijonhufoud (7 (1987) "Rational Expectations and Monetary Institutions" in de Cecco M. and Fitoussi J-P (eds) Monetary Theory and Economic Institutions London, Macmillan.

Lerner A. P. (1951) The Economics of Employment New York, McGraw-Hill.

Lucas R. E. Jr. (1972) "Expectations and the Neutrality of Money" Journal of Economic Theory 4 (2) 103-124. and Rapping L. R. (1969) "Real Wages, Employment and Inflation" in Phelps E. S. et. al. The Microfoundations of Bmployment and Inflation Theory London, Macmillan.

Minford P. (1980) "A Rational Expectations Model of the United Kingdom under Fixed and Floating Exchange Rates" in Brunner $\mathrm{K}$. and Meltzer A. H. (eds.) Carnegle-Rochester Conference Serles on Public Policy Vol. 12 293-355.

Modigliani F. (1977) "The Monetarist Controversy or, Should We Forsake Stabilisation Policies?" American Economic Review 67 (Harch) 1-19. and Brumberg R. (1954) "Utility Analysis and the Consumption Function: Interpretation of Cross-section Data" in Kurihara K. (ed.) Post-Keynestan Economics New Brunswick d. J., Rutgers Univ. Press. Patinkin D. (1948) "Price Flexibility and Full Employment" American Economic Revlew 38 (Sept.) 543-564. (1956) Money Interest and Prices (1st ed.) New York, Harper \& Row.

Phelps E. S. (1967) "Phillips Curves, Expectations of Inflation and Optimal Unemployment over time" Bconomica wS. 34 (Aug.) 254-281. Phillips, A.W. (1954) "Stabilisation Policy in a Closed Economy" Bconomic Journal 64 (June) 290-323. 
Samuelson, P.A. and Solow, R.M. (1960) "Analytical Aspects of Anti-Inflation Policy" American Economic Review 50 (Hay, papers and proceedings) 177-194.

Sargent T. J. and Wallace N (1976) "Rational Expectations and the Theory of Economic Policy" Journal of Monetary Economics 2 (May) 169-183. and (1982) "The Real Bills Doctrine versus the Quantity Theory: a Reconsideration" Journal of Political Economy 90 (Dec.) 1212-1236.

Tobin J. (1977) "Inflation Control as a Social Priority" mimeo, Yale University.

Vaubel R. (1986) "Currency Competition versus Governmental Money Monopolies" The Cato Journal 5 (Winter) 927-942.

Wallace N. (1982) "Panel Discussion" in Interest Rate Deregulation and Monetary Policy Federal Reserve Bank of San Fransisco.

Weldon J. C. (1973) "On Money as a Public Good" mimeo, McGill University. White L. (1984) Free Banking in Britaln: Theory, Experience and Debate 1800-1845 Cambridge, Cambridge Univ. Press. 
8601C Greenwood, Jeremy and R. Preston MicAfee. EXTERNALITIES AND ASYMMETRIC INFORMATION.

8602C Dinopoulos, Elias and Mordechai E. Kreinin. IMPORT QUOTAS AND VERS: A COMPARATIVE ANALYSIS IN A THREE-COUNTRY FRAMEWORK.

8603C Clarete, Ramon and John Whalley. COMPARING THE MARGINAL WELFARE COSTS OF COMMODITY AND TRADE TAXES.

8604C Wigle, Randa11. CANADIAN TRADE LIBEPAIIZATION: SCALE ECONOMIES IN A GLOBAL CONTEXT.

8605C Parkin, Michael. DOMESTIC MONETARY INSTITUTIONS AND FISCAL DEFICITS.

8606C Dinopoulos, Elias and Ian Wooton. INTERNATIONAL TRADE AND THE ACQUISITION OF SKILIS.

8607C Kawasaki, Seiichi and John McMillan. THE DESIGN OF CONTRACTS: EVIDENCE FROM JAPANESE SUBCONTRACTING.

8608C Williamson, Stephen D. LIQUIDITY, BANKING, AND BANK FAILURES.

8609C Grossman, Gene M. and Carl Shapiro. COUN'IERFEIT-PRODUCT TRADE.

$8610 \mathrm{C}$ Deardorff, Alan V. WHY DO GOVERNMENTS PREFER NONTARIFF BARRIERS?

8611C Horstmann, Ignatius and James R. Markusen. LICENSING VERSUS DIRECT INVESTMENT: A MODEL OF INTERNALIZATION BY THE MULTINATIONAL ENTERPRISE.

8612C Thursby, Jerry G. and Marie C. Thursby. BILATERAT TRADE FLOWS, THE LINDER FYPOTHESIS, AND EXCHANGE RISK.

$8613 \mathrm{C}$ Clarete, Ramon and John Whaliey. EQUILIBRIUM IN THE PRESENCE OF FOREIGN EXCHANGE RREMIA.

8614C Wooton, Ian. TOWARDS A COMMON MARKET: FACTOR MOBII.ITY IN A CUSTOMS UNION.

8615C St-Filaire, France and John Whalley. SOME ESTIMATES OF TRADE FLOWS IN BANKING SERVICES.

8616C Evenson, Robert $\Sigma$. and Cayetano Paderanga Jr. RURAL I.RECUF. MARKETS, TRANSACTION COST EN:D FEETILITY.

8617C Fried, Joel and Peter Howitt. FISCAL DEFICITS, INTERNATIONAL TRADE AND WELFARE.

8618C Trela, Irene, John Whalley and Randall Wigle. INTERNATIONAL TRADE IN AGRICULTURE: DOMESTIC POLICIES, TRADE CONFLICTS, AND NEGOTIATING OPTIONS.

8619C Markusen, James R. and Anthony J. Venables. TRADE POLICY WITH INCREASING RETURNS AND IMPERFECT COMPETITION: CONTRADICTORY RESULTS FROM COMPETING ASSUMPTIONS.

8620C Hunter, Linda and James R. Markusen. PER-CAPITA INCOME AS A DETERMINANT OF TRADE.

8621C Jones, Rich and John Whalley. A CANADIAN REGIONAL GENERAL EQUILIBRIUM MODEL AND SOME APPLICATIONS.

8622C Freeman, Scott and Gregory W. Huffman. INSIDE MONEY, OUTPUT, AND CAUSALITY.

8623C Hamilton, Colleen and John Whalley. DEALING WITH THE NORTH: DEVELOPING COUNTRIES AND GLOBAL TRADE NEGOTIATIONS.

8624C Williamson, Stephen D. LAISSEZ FAIRE BANKING AND CIRCULATING MEDIA OF EXCHANGE.

8625C Whalley, John. WHAT HAVE WE LEARNED FROM GENERAL EOUILIBRIUM TAX POLICY MODELS? 
8626C Bhatia, Kul B. SHORT RUN AND LONG RUN IN THE THEORY OF TAX INCIDENCE.

8627C Jones, Rich and John Whalley. REGIONAL EFFECTS OF TAXES IN CANADA: AN APPLIED GENERAL EQUILIBRIUM APPROACH.

8628C Nguyen, Trien T. and John Whalley. GENERAL EQUILBRIUM WORLD TRADE UNDER BILATERAL QUOTAS.

8629C Clarete, Ramon L and James A. Roumasset. THE RELATIVE COST OF INDUSTRIAL AND AGRICULTURAL PROTECTION POLICIES USING PHILIPPINE DATA.

\section{7}

8701C MCMillan, John, John Whalley and Zhu Lijing. INCENTIVE EFFECTS OF PRICE RISES AND PAYMENT-SYSTEM CHANGES OF CHINESE AGRICULTURAL PRODUCTIVITY GROWTH.

8702C Wooton, Ian. CAPITAL, SKILLS, AND INTERNATIONAL TRADE.

8703C Ryan, Cillian. TRADE IN THE PRESENCE OF ENDOGENOUS INTERMEDIATION IN AN ASYMMETRIC WORLD.

8704C Kennan, John and Raymond Riezman. OPTIMAL TARIFF EQUILIBRIA WITH CUSTOMS UNIONS.

8705C Feenstra, Robert C. and Tracy R. Lewis. NEGOTIATED TRADE RESTRICTIONS WITH PRIVATE POLITICAL PRESSURE.

8706C Brecher, Richard A. POLICY-INDUCED INFLOWS OF FOREIGN CAPITAL IN THE PRESENCE OF RIGID-WAGE UNEMPLOYMENT.

8707C Harrison, Glenn W., Richard Jones, Larry J. Kimbell, and Randall Wigle. HOW ROBUST IS APPLIED GENERAL EQUILIBRIUM ANALYSIS?

8708C Jones, Richard and John Whalley. REGIONAL BALANCE SHEETS OF GAINS AND LOSSES FROM NATIONAL POLICIES.

8709C Markusen, James R. TRADE IN PRODUCER SERVICES AND IN OTHER SPECIALIZED INTERMEDIATE INPUTS.

$8710 \mathrm{C}$ Markusen, James R. PRODUCTION, TRADE AND MIGRATION WITH DIFFERENTIATED, SKILLED WORKERS.

8711C Markusen, James R. INTRA-FIRM SERVICE TRADE BY THE MULTINATIONAL ENTERPRISE.

8712C Parkin, Michael. MONETARY POLICY AND AGGREGATE FLUCTUATIONS.

$8713 \mathrm{C}$ Smith, Bruce D. LEGAL RESTRICTIONS, "SUNSPOTS", AND CYCLES.

8714C Harrison, Glenn W. and E.E. Rutstrom. TRADE WARS AND TRADE NEGOTIATIONS: A COMPUTATIONAL APPROACH.

8715C Smith, Bruce D. MONEY AND INFLATION IN THE AMERICAN COLONIES: FURTHER EVIDENCE ON THE FAILURE OF THE OUANTITY THEORY.

8716C Wonnacott, Paul and R.J. Wonnacott. UNILATERAL FREE TRADE VS. A CUSTOM's UNION: THE FURTHER SEARCH FOR A GENERAL PRINCIPLE.

8717C Neary, Peter. TARIFFS, QUOTAS AND VOLUNTARY EXPORT RESTRAINTS WITH AND WITHOUT INTERNATIONALLY MOBILE CAPITAL.

8718C Schmitt, Nicolas. TWO-COUNTRY TRADE LIBERALIZATION IN AN ADDRESS MODEL OF PRODUCT DIFFERENTIATION.

8719C Greenwood, Jeremy and Gregory W. Huffman. ON MODELLING THE NATURAL RATE OF UNEMPLOYMENT WITH INDIVISIBLE LABOR. 
8801C Bhatia, Kul B. FOREIGN TRADE AND INCOME DISTRIBUTION: THE CASE OF MALAYSIA.

8802C Greenwood, Jeremy, Zvi Hercowitz, and Gregory W. Huffman. INVESTMENT, CAPACITY UTILIZATION AND THE REAL BUSINESS CYCLE.

8803C Kymlicka, B.B., John Whalley, and Ronald J. Wonnacott. THE CANADA-US FREE TRADE AGREEMENT: REACTIONS AND EVALUATIONS.

8804C Trela, Irene and John Whalley. DO DEVELOPING COUNTRIES LOSE FROM THE MFA?

8805C Whalley, John and Randall M. Wigle. ENDOGENOUS PARTICIPATION IN AGRICULTURAL SUPPORT PROGRAMS AND AD VALOREM EQUIVALENT MODELIING.

8806C Courchene, Thomas J. THE FREE TRADE AGREEMENT: REFLECTIONS OF A MARKET NATIONALIST.

8807C Laidler, David. MONETARISM, MICROFOUNDATIONS AND THE THEORY OF MONETARY POLICY. 